\title{
We are playing football: seeing the game on Panapompom, PNG
}

\section{Will Rollason, Brunel University}

\section{Introduction}

This is a paper about football played by Panapompom people from the Louisiade Archipelago, part of Milne Bay Province, Papua New Guinea (PNG). In it, I explore the shifting positions that Panapompom people prospect after through football. The paper argues that by playing, Panapompom people seek to become like white people and achieve development. Through their engagement with the game, they detach themselves from their position as natives of culture, while only achieving relative similarity to the white identity they aspire to. Panapompom football therefore opens up a problematic space between cultural specificity and global sameness. The challenge here is to sustain the spirit of the projects that PNG people pursue relative to local cultural forms and forms of global culture without reducing their efforts to either.

To summarise the argument of this paper very briefly, I begin with the way in which football became an ethnographic problem for me. Football became interesting not because it was culturally distinctive or modified, but because Panapompom people made it appear so obviously and against anthropological expectations as football. I go on to present two possible frames for interpreting this problem. The first is a frame based on the idea of relativity to a cultural context, a well-used anthropological strategy. The second fits Panapompom football into a discourse on global sport, a common approach amongst world sporting bodies and agencies linking sport to development efforts.

Neither of these conventional frames will do. Framing Panapompom football in terms of native culture obscures exactly what Panapompom people were interested about in football: it is a globally recognisable game; as such it mattered profoundly that Panapompom people played football. Yet framing football as a universal sporting institution is equally inadequate: it erases the specific political project that was embedded in Panapompom people's approach to organising football.

To resolve this impasse, I argue that football provides a context in which Panapompom people can judge themselves in relation to others, who are defined in terms of colonial and post-colonial discourses on 'development'. The specific project of playing football on Panapompom locates Panapompom people in a problematic interstitial position: neither culturally located nor globally framed, they find themselves caught between the terms on which they might be identified. More precisely, it defines Panapompom people as subjects on the move, 'prospecting' (Battaglia 1995; 1999) from what they regard as their cultural location into a space not so marked by cultural specificity. Panapompom people become visible relative to but never identified with systems of classification and discourse (Butler 1995; 1993; 2005). ${ }^{1}$ Given recent scholarship that treats Melanesians as inescapably 
constituted by gift exchange and imprisoned in their own 'partibility' (Mosko 2010; Englund and Leach 2000; Sahlins 2005), this critique is important for reimaging local political projects in the region.

\section{The context of football}

\section{Football is obvious}

In May 2005, handwritten notices appeared in the hamlets that circle the coast of Panapompom, pinned to trees, stuck into the rustling thatch of sago-leaf walls, or stapled to the plywood doors of permanent buildings. This notice has been written by Isso, the Teacher in Charge of the Panapompom Elementary School. The notice read as follows:

NOTICE 19-05-05

Any interested sportsman/woman who wish to enjoy himself/herself during the weekends (Saturday) here at Panapompom Mini Sports Association, you are "MOST WELCOME".

Be informed that you are to address the names of your teams to the Elementary Teachers as soon as possible.

The sooner you organise yourselves, the sooner we will kick off.

\section{Em Tasol}

$10 Q$

Mr I Kitah

The new notices were accompanied by plain sheets of paper, on which people soon began to sign their names, registering their interest in the new Association. ${ }^{2}$ When I saw the notices advertising the Association, I was immediately attracted to it not as an object of research, but as something I could do to have fun and relax every Saturday afternoon. I therefore signed my name under a growing list on the paper that was stapled to the door of the community hall in our local hamlet.

This demonstrates something that is of the utmost importance for this paper: what was going on did not seem at all strange to me. 'At work' at that time, I was busy investigating local men's experiences gathering marine resources, exploring their attitudes to technology, custom and community life. Just over the horizon of these issues were questions about witches, God and the post-colony and I was alive to the need to delve into these issues for underlying concerns that could help to make what seemed unconnected and incomprehensible ideas make sense (Geertz 1973). In Wagner's terms, I was busy inventing a cultural context (Wagner 1975; 2001) in which to make sense of Panapompom life. By contrast, I approached playing football simply as playing football - without seeking to render it comprehensible by placing it in a 'cultural context'. Football seemed to me to be completely transparent, invisible to my ethnographic vision.

Why was this so? In large part, this was because of the way in which Panapompom people presented football to me, and spoke about it themselves. This they did through images of football that made it very hard to see the game as anything else. 
Look at this picture:

$<<$ FIGURE ONE $>>$

This, I suggest, is a canonical image of a football team. The team in question is the first string team from the island of Panapompom), which played against the nearby village of Ebola in a tournament organised in October 2005.

I suggest that these people could not easily be anything but footballers. I think that this is the case because of the way they manifest themselves here - that is in the form of an image. Isso, the writer of the initial notice announcing the Association is in the number 13 shirt with the white headband. He took the lead in arranging the players to pose for this picture, but on the whole they were familiar with how they should stand in order to figure the desired image.

Here the players present themselves not merely as a football team, but as a football team presenting themselves for a photograph. The picture is not as slickly done as it might be, but the formula should be familiar: this image belongs to a genre of institutional photography that includes school class pictures and workplace pictures, as well as sports teams in its purview. In this case, the combination of sports uniforms in a particular style, combined with the typical 'lined-up' posing of the subjects - which the people in the picture arranged for themselves - inescapably displays a football team, even in the absence of other canonical elements of such images, such as a ball or trophy.

The footballers of the new Sports Association depended heavily on images of this type to define what it was that they were doing. In the following section, I describe the work that Panapompom people did to achieve this effect.

\section{The visibility of football}

It was clear to most of the lads, as well as other people who took an interest in the Association, that success as players depended on acting in particular ways, ways that would perform football as a reproduction of the lawful game played by dimdims, white people. White people live in countries such as Australia, England and America. Distinguished from black 'natives', naitib, white people are thought of as wealthy, disciplined and lawful (c.f. Bashkow 2006). In terms of football, dimdims are imagined as the source of, and final authorities on the game. In reproducing football, Panapompom people were doing their best to demonstrate their similarity to football as it is played by these white people. What was significant about this for Panapompom people was how the game established a link to other instances of football, played elsewhere, and which served to separate football from its temporal location on the island, and to suggest its likeness to white people's football.

Hence, football for Panapompom people was an athletic exercise on the pitch, but the vast bulk of the effort and concern that people put into it was directed at the production or reproduction of football as a visual aesthetic effect, an image of football. People referred to this effect as pitibal ana awa, the appearance of football: particularly important for Panapompom people was having football strips (uniforms) to play in. 
Panapompom people know what football looks like from magazine or newspaper photographs and from games in Alotau, the provincial capital, where well-turned-out and professional-looking teams played each Saturday. These sources acted as mediators for a televised football culture which was hardly ever accessible to Panapompom people: football is not usually shown on television in PNG, and Panapompom people had no access to television in any case. VCDs of famous football matches, usually from past FIFA World Cup competitions were available in Alotau, and I believe that it was these which constituted the ultimate authority on the appearance of the sport. While the athleticism of the players could mostly be taken for granted, creating these visual effects proper to football was much more problematic for Panapompom people.

There were four clubs involved in the Association, which corresponded broadly with the major residential divisions of the island. Each club had two football teams. Rather than being organised in two divisions, these teams competed in a single league, and each pair of teams shared a name and a strip. The following table summarises the teams and their strips, while the graphic shows the spatial distribution of the teams.

$<<$ FIGURE TWO >>

\section{$<<T A B L E$ ONE $>>$}

Football strips are extremely costly to buy. They are not available locally, but must be purchased either in Alotau, a K100 round trip away on a workboat, or in Bwagaoia, the nearest urban centre. In Alotau, a strip costs in the region of K350. ${ }^{3}$ Numbers, which Panapompom people felt enhanced a strip very greatly, cost extra - in the region of K5-7 each. A goalkeeper's outfit might add an extra K150 to the overall price. It has been estimated that the average annual income for the Province is $A \$ 130$, about K400 at the time (Skewes et al. 2002, 3). This estimate is generous for Panapompom where, although I was unable to gather accurate data on this point, many of the younger men earned only in the region of K100 a year from bêche-de-mer (c.f. Jeff Kinch 2002). ${ }^{4}$ Strips were in fact purchased either by individuals with very considerable funds (in the case of Trials and Yalasi), borrowed (in the case of Kools), or received as gifts (Seakings). Strips were either outrageously expensive to buy, or acquiring them was a difficult process that simply could not be relied upon.

In this context, and in my role as treasurer for Kools club, drawn from some of the poorest people on the island in terms of money, I suggested that rather than purchase a football strip proper, we might save a great deal of money by buying a set of matching polo shirts instead. At a cash and carry in Alotau, we would make a saving of several hundred kina on the price of a proper strip. My friends in the club agreed with my mathematics, but did not recognise that what I was saying was rational. My assumption was that football strips were only barely necessary to the game. This was an opinion born of playing in parks and playgrounds as a child without any equipment whatsoever, and an upbringing, which now seems very Protestant, that had impressed on me the ethical and moral aspects of the game as an inner process, rather than an outward display. 
For Panapompom people, the role of the strips and of display was far more important, and valued unequivocally in the positive. Towards the beginning of the season, Kools still did not reliably have a football strip because of the arrangements by which we borrowed them. On one occasion when we did not have the shirts, and were playing bare-chested to distinguish us from the other team in their jerseys, one of the linesmen, a player from Seakings, remarked to me, 'You can win and win, but when you get to the final, you can't win without a strip.' Yemesa, one of our full-backs repeated the sentiment when he said, 'putbal ana awa he jersey: nigea jersey, nigea point, ya ba hot eliyamiu', which roughly translated means, 'the appearance of football is the jersey: no jersey, no points, I'm telling you.' Football, it appeared was not possible if it did not appear in a certain way. Constituted as a visual form, it appeared to demand recognition as such, and to provide a context in which it was possible.

The key-word here is context: football became the common ground on which our action could be mutually comprehensible: for Panapompom people and I, players sharing the Association, there was never any doubt that we were playing football. Football, created by the image of football strips, served to stake a claim to a sort of relationship organised around the apparent, tactile impression of football figured on the surfaces of people's bodies. Here football is a means of organising relationships between persons, because the frank appearance of football seems to circumscribe its ability to be anything else, covering over potential differences, and eliciting its recognition relative to other instantiations of the game. Football becomes powerful in this reading insofar as it is repeated. Better, in Butler's terms it is reiterated (Butler 1990; 1995) - said again, with inevitable differences, producing a copy of a copy. The act of reiteration defines the discursive space within which the reiteration takes place: enacting football creates football as the intelligible frame for the acts that constitute it. ${ }^{5}$ This is a context in the sense that Moore employs the term: a metaphoric 'domaining' of ideas such that relationships between them become imaginable, evoked by the act of reiteration itself (Moore 2004).

\section{Cultural contexts}

This last claim on the notion of context is a problematic one, however, especially from an anthropological perspective. This is because of the way in which anthropological explanations of what other people do are usually phrased in terms of this idea.

Roy Wagner has written:

A context is a part of experience - and also something that our experience constructs; it is an environment within which symbolic elements relate to one another; one that is formed by the act of relating them (Wagner 1975, 37).

The point that Wagner is making here is that what other people do has to be understood in terms of an 'environment' within which they make sense. The 'environment' that Wagner is describing is this system, or model, of relationships (Strathern 1995) ${ }^{6}$ - the 'crib' by which we can parse the odd things that other people do for significance. Wagner argues that as ethnographers, the most important contextualising that we have at our disposal is 'culture'. 
However, faced with 'global' forms such as football, this method of contextualisation presents certain problems. Wagner's starting point for his account of the 'invention' of contexts is the encounter between people who are very different. He takes his experience as a young ethnographer in PNG in the 1960s as a model. He contends that ethnographers 'invent' culture in order to systematise the differences or relationships between what they expect to happen - their own values and representations of the world - and what their informants do and expect (Wagner 1974).

What happens, however, when these differences are not so apparent - when Papua New Guineans self-consciously and carefully reiterate football, for example? In this situation, the notion of context tends to enforce difference, even against the political aspirations of the people we try to understand (Battaglia 1999).

The previous quotation from Wagner continues:

The elements in a conventionally recognised context seem to belong together, as elephants, tents, clowns, and acrobats "belong" to a circus (Wagner 1975, 37).

A context, once 'invented' tends to become compulsory. Thus, to invoke a circus calls to mind clowns and elephants. The implications of this sort of position are very far-reaching: culture, once invented as a system of meaningful relationships is very hard to escape from.

The implications of this sort of model are very important in anthropology, especially in branches of the discipline that deal with cultural 'imports' such as football in Panapompom (Sahlins 1981; Sahlins 1995; Sahlins 2000 afford excellent examples of this approach). The central conceit is that cultures form totalising systems, which comprehend entire worlds: interpretation depends on a context that is coextensive with whatever it is that 'natives' do. ${ }^{8}$ It is for this reason that culture becomes compulsory and hard to escape. Cultural imports cannot be effective in themselves but are parsed through a notion of culture which is identified with native subjects' consciousness. What becomes interesting is therefore distortions and appropriations of these 'new' elements, not the form of the ideas or actions that constitute them (Robbins 2007). ${ }^{9}$

In general terms, the effect of notions of cultural context is to enforce cultural transformation on incoming objects and ideas. This is particularly obvious when we consider the way 'global' commodities and ideas are 'appropriated' by indigenous cultures. Whereas the global scene threatens to flatten difference and meaning into a singular field of commodities anthropology works to diversify that field by exploring the specific genii of native peoples (Englund and Leach 2000; c.f. Moore 2004; Mosko 2007; 2010).

Returning to sports, it is quite clear that 'global' games such as football and rugby, especially as they appear in a PNG, even a Pacific context, are typically treated in this way. Current interpretations of sports in PNG revolve around the ways in which the organisation of teams and competitions are linked to 'culture' in the form of 'vernacular' (Bashkow 2006) social and cultural arrangements that are conceived of as being basic to the ways in which PNG people know themselves (examples of this broad approach include Foster 2006; Leach 2006; 
Mosko 2007; Read 1959; Wilde 2004; Wolff 2005). Sports teams are therefore seen as extensions or analogues of other organisations such as clans, or institutions such as warfare or canoe racing - categories which have been 'stretched' to accommodate new ways of acting (c.f. Sahlins 1981). The upshot is that culture itself is continually reiterated as a context, controlling what can appear in its terms, while global forms such as football can never appear as 'themselves'.

It is from this perspective that my claim that football is difficult to imagine as anything else becomes problematic because the reiteration of football defines the context in which it appears. ${ }^{10}$ The notion of cultural context tends to force our analyses back towards the imagined centres of 'authentic' or 'native' cultural life, casting explanations in terms of what people used to do. My claim asks us to imagine a disjuncture or break - a sharp limit to the transformative capacities of culture - in which something comes in from the outside and stays what it is. ${ }^{11}$

\section{Common interests}

There is a tradition of thinking in this way, however, both within anthropology and beyond. The break or limit that I am proposing that football introduces would be easy to identify with the rupture of modernity, and therefore to align what I have to say with modernisation theories in their various guises - theories in which capitalism, the nation state or democracy have 'natural' and 'necessary' effects on host peoples (Holston 1989; Scott, 1988).

With respect to sport, this sort of position is articulated by the International Olympic Committee in its declaration of the Fundamental Principles of Olympism:

11

1. Olympism is a philosophy of life, exalting and combining in a balanced whole the qualities of body, will and mind. Blending sport with culture and education, Olympism seeks to create a way of life based on the joy of effort, the educational value of good example and respect for universal fundamental ethical principles.

\section{$[\ldots]$}

4. The practice of sport is a human right. Every individual must have the possibility of practising sport, without discrimination of any kind and in the Olympic spirit, which requires mutual understanding with a spirit of friendship, solidarity and fair play (International Olympic Committee 2007, 11).

The International Olympic Committee is not in the business of questioning the cross-cultural validity of the notion or effects of sport. Rather it assumes that sports will have certain effects on the people who engage in sporting activities, and these effects can be harnessed to socially useful ends. This is particularly obvious in the deployment of sport in the developing world:

Sport can be a positive force in societies facing big social challenges. Through sports activities, children and youth can learn to cooperate and respect each other. The values of 
sport can increase dialog and tolerance, and promote social inclusion (Norwegian Olympic Development Committee n.d., 2).

Specifically in the context of football in PNG, similar language is in use:

The recent partnership entered into between the United Nations system in Papua New Guinea and the Oceania Football Confederation (OFC) will help to achieve the goal of utilizing football as a development tool for the youth in the region, Reynald Temarii, Senior VicePresident of FIFA, the International Football Federation, has said.

\section{$[\ldots]$}

"This initiative is in recognition of the fact that football can make the world a better place," said Mr. Temarii (UNDP 2008).

In all these cases, sports appears as something that has a reality or effectiveness of its own, which is not submitted to a translation or transformation process, but which rather offers to discipline host societies (c.f. Appadurai 1996). Maguire points in a similar direction when he describes the field of global sport as consisting in central zones, to which sport is an integral part of popular culture, and other, peripheral zones, to which it is exported. Panapompom would represent a 'zone of emulation' in his terms - an area in which sports are adopted and copied, perhaps as part of other projects (Maguire 2005).

This is a position which is not wholly absent from the anthropology of globalisation and capitalist expansion. LiPuma, for example, in the context of capitalism in PNG has argued that we should expect capitalism to effect changes of particular kinds because as a socioeconomic form, capitalism embeds its own modes of subjectivity or personhood (LiPuma 1995; 2000). Robert Foster, examining the impact of commodity economies, again in PNG, has made a very similar argument, contending that because commodities are identifiable, discrete and serial, they tend to compel their consumers to appear in similar ways through the consumption choices that they make (Foster 1999; 2002; 2008; c.f. Scott 1998; Anderson 1991). ${ }^{12}$

However, it is necessary to exercise caution. Panapompom people did not, in fact, share the aims of the IOC or its commitment to 'universal fundamental ethical principles'. Here the distinction between Butler's reiteration and wholesale replication is at issue. Reiteration in Butler's terms signals a formal gesture that might signify the attitude of a subject. In fact the act of reiterating a performance elicits the subject as one who 'has' a position: it makes it appear that there is something 'behind' the performance, causing it. Butler's (1990) argument is that straight sexual performances are reiterations that perform a discourse about a 'natural' body and gender identity causing sexual desire. Her model of sexuality inverts this progression to make sexuality begin with the performance; appearances become logically prior, creating the (naturally) gendered, sexed body through the reiteration of sexual practices (Butler 1999). For Butler the critical potential of the idea of repetition lies in its capacity to displace assumptions about the foundations of sexuality by linking sexual acts 
to bodies and genders that only uneasily ' $\mathrm{fit}^{\prime}$ ', as in the case of the drag queen who performs straight female sexuality as a gay man (Butler 1990; 1993).

Therefore if we pursue the idea that Panapompom people reiterated football, we should expect to find the very act of repetition displacing the 'inner' meaning of the game. Rather than pursuing an ethical universalism Panapompom people were, as we shall see, much more interested in a politics that was centred around exclusion and self-hatred rather than the humanist openness of the IOC. When they play football 'straight' this might look as if Panapompom people subscribe to the IOC's liberal universalism, but in fact the fit with Panapompom people's aims was not a good one. We can thus reduce Panapompom football neither to a foundational 'native culture' nor to a foundational 'universal sport'. Rather we need to understand it as a political project that exists exactly in the act of reiteration that entails a movement between these two positions as Panapompom people imagined them.

\section{The genealogy of football}

In order to understand the dimensions of this political project and to map its strategies, we need to understand the role that football takes in political projects and aspirations that Panapompom people entertain. These have their roots in the colonial and post-colonial past of the island. My interpretive strategy is to show how a move away from 'native culture' and towards similarity might be a component in this political project. In this section, I outline how Panapompom people saw football as such a political project, before going on to explore where that project comes from.

\section{Fighting and the notion of development}

The lads ${ }^{13}$ who became my informants had previous experience with association football, called putbal, pitibal or soka, in the form of the Panaeati Sports Association, which had been active until a few years previously on the neighbouring island of Panaeati. This association had collapsed because the officials elected to run it had been unable to deal with what everyone agreed was the most pressing problem for local football: fighting. Fights were quite clearly common and occasionally large and violent. Although I do not believe that anyone was injured seriously in football related fighting, nor that houses or other property were ever badly damaged, both the lads who played and elder community figures decried fighting as a serious blemish on the reputation of the community. The new Association on Panapompom - the first sports association that Panapompom people had ever had to themselves - was a new chance to display the community as a home of orderly and lawful people. Nevertheless, fighting was present from the beginning of the Panapompom Association. The first outbreak came in the second pre-season warm-up match, and there were two further serious fights involving most of the players and supporters. On one of these occasions, much to the general shame of the congregation, the pastor was involved in a fight.

The prevalence of fighting was taken for granted by many people. Double, the vice-president of the Association gave me one explanation that accorded well with other people's opinions, however. He explained that football is very energetic: it results in people breathing heavily and quickly; it makes the eyes red and watery; it causes people to sweat and shake. He said 
that these were not only the symptoms of exercise, but also of anger. It followed that footballers were prone to become angry just by virtue of playing the game: if they are jeered by the crowd or fouled by an opponent, they are likely to turn to anger and violence because their bodies are already in a state close to anger. Thus it is significant that the expression yawalina kaukaubwana, short breath, can be an attribute either of someone with little patience or forbearance, who gets angry easily, or of someone who gets out of breath swimming or running.

One of the key techniques by which Panapompom people hope to suppress fighting is the cheer. Cheers are shows of goodwill that teams exchange before and after games of football. Before the game, the teams line up in the centre of the pitch to hear a brief address from the referee, who also tosses a coin to decide who will kick off. After these formalities are completed, the captain of one of the teams will call to his team mates to 'give a cheer to our brothers on the other team'; the lads call out 'hooray' and clap their hands. The other team returns the cheer. After the game, both teams are supposed to go into a huddle in the middle of the pitch, where they again exchange cheers, shake hands and clap one another on the back.

This institutionalised show of goodwill visually demonstrates for spectators and players alike 'the appearance of the game' glossed as happiness (yaliyaya) and respect for the rules (logugui ana awatauwan). This appearance is thought of explicitly as the way in which white people far away in England, Germany and Brazil play football. White people are known to be people who obey the law, whose social relations are not spoilt by violence, and in whose eyes the violence of PNG people becomes a primitive savagery (c.f. Kulick and Wilson 1992; Rollason 2008a; Sykes 1999).

The effort expended on the appearance of football in terms of strips and suchlike, combined with this emphasis on the moral appearance of football, suggests that the attempt made by Panapompom people to reproduce football as an image is also an attempt to co-opt the authority and ways of acting proper to white people into a political project pursued by Panapompom people. At the heart of this project is an effort on the part of Panapompom people to show their (moral) qualities as a visual effect manifested on the surfaces of their bodies (Foucault 1995, 170; c.f. Strathern 1979).

This is the project that is at the heart of Panapompom 'development'. Panapompom people usually gloss 'development' as a 'change in the appearance of the place', panuwa ana awa ana sensi. Development as a project of social change involves altering the visual forms of social life by altering architecture (roofing iron in exchange for thatch), the body (clothing), language (people should speak English), and manners of comportment, gesture and behaviour (the end to profanity, licentiousness, and other aspects of custom). The new goods and technologies that Panapompom people will acquire - rice in exchange for yams, permanent buildings, dinghies and workboats - always carry an association to white people: a permanent house is limi-dimdim, white-person-house, a workboat is waga-dimdim, whiteperson-boat, and so on. Panapompom people do not so much come to posses the forms of development, but are possessed by them, shifting into a position that approximates more 
and more closely to the position occupied by white people, which they reiterate as a claim to the quality of development (Rollason 2008a).

This project is concerned with covering over the violence implicit in the football game with a show of happiness that will demonstrate its similarity to white people's sociality. Football is therefore a moment in this project of development. The effort of cheering and shaking hands takes the form of a metaphoric cover, deferring the experience of the game from the players to another, third-party perspective that is only very approximately located. It is certainly not located in the players themselves, whose exertions lead them to anger; nor is it really to be found in the audience, who usually get so engrossed in the game that they issue torrents of abuse and may start fights themselves. This suggests an interpretation that would see this perspective as being located with absent white people. As such, cheering is very similar to the sort of contextualising work that the mimetic reproduction of football performs: it establishes a context in which things make sense in particular terms. Here, those terms are the terms of white people and their way of life.

\section{Colonial demands}

What is the genealogy of these ideas? To understand the context in which Panapompom people understand themselves to be working we need to consider the place that the watching, judging white man has had in the recent history of the region, and how Panapompom people have engaged with this figure.

This is worth dwelling on because of the systematic use of football and other sports in colonial pastoral projects. It was certainly the mission that introduced cricket, football and netball to the Louisiades; these sports have a long history of involvement with missions as means of inculcating Christian values in converts, both in PNG (Wetherell 1996) and further afield (MacAloon 2006; Mangan 2006)). Once government, as opposed to mission organised, primary schooling was established on Panaeati in 1955-56 (Teague 1956), it is clear that this school offered sport, as the mission schools did, as an integral part of its educational programme. Beyond education, patrol reports from the 1950s note with approval that local people are involved in sports associations playing football, cricket and netball (Davies 1954; Geelan 1952). Sport was therefore an integral part of the colonial project from a relatively early period, a feature of local life that developed into the 1960s and 70s (Standing 1971; Gerrard 1969).

1942, the year the Second World War arrived in this region, is a useful watershed in thinking about the recent history of colonial governance in this region of the Louisiades. This was not a moment of 'contact', but an important epoch in an ongoing colonial history. The explorer Torres made 'contact' with the Louisiades in the early seventeenth century. A series of other explorers followed between that time and 1849, when Owen Stanley made the first detailed observations of the islands and their people (Battaglia 1990, 19-20).

Missionaries soon followed: Panaeati, Panapompom's neighbour across the Deboyne Lagoon, became home to an important Methodist mission station in 1892 (Berde 1974; 1979; Bromilow 1929). In the pre-war period, Missionaries certainly had an important pastoral role in island life, although it is hard to judge from the available sources, which are 
either written by the pastors themselves, or represent recent oral histories by Christian islanders, what effect exactly the mission had.

Traders were also present in the pre-war period, working in the western arm of the Louisiades (Battaglia, 1990). These men, who were either of European or East Asian origin, produced copra and bought marine produce. Gold mining operations were also present on Misima (Nelson 1976). It was the copra trade, indeed, which originally brought a permanent population to Panapompom. The Australian trader Mr Munt, as he is locally remembered, established a considerable coconut plantation on the south coast of Panapompom immediately before the war. He was also involved in gold mining, and had plantations elsewhere in the islands. Prior to the establishment of this plantation, the only people living in the Deboyne Lagoon were Panaeati people. They gathered sago and hardwoods on Panapompom, but did not stay: the island had an evil name as a haunt of witches, olal, monsters, silapa, and crocodiles which did indeed infest the sago swamps, along with disease-carrying mosquitoes which were largely absent from Panaeati. ${ }^{14}$

1942 , then, is significant not because of any reference that it has to 'contact', but because this date marks a shift from what appears to have been an ad hoc assemblage of 'colonial' people and institutions exercising various kinds of control and influence over local people, to an attempt systematically to govern the Louisiades. Nelson has argued that the Second World War as a whole had the effect of sharpening Australian administrators' feeling of obligation to their Papuan subjects in the then Territory of Papua (Nelson 1982; Nelson 2000; Connell 1997). This concern is obvious in administration records for the Louisiades, where Australian Patrol Officers are concerned that the depredations of the military, conscripting men as carriers, may have fatally affected the viability of some communities (Mader 1942; Smith 1943; James 1944). Regardless of the cause, however, it seems clear that administration shifts in 1942 away from being essentially the light regulation of expatriate businesses and churches, to a more intensive concern with the quality of the native population (MacLeod 1946a). 1942 marks the beginning of intensive governance in the Louisiades.

Governance across what was then the Commonwealth of Australia's Territories of Papua and New Guinea was carried out by mobile government officers undertaking patrols. ${ }^{15}$ The Louisiades, in the Misima Sub-District, were no exception. From the Sub-District Headquarters at Bwagaoia, Patrol Officers set out to inspect the various villages of the surrounding islands and to dispense justice, advice, medicine and banking services, normally travelling by boat. These patrols then yielded a number of reports and documents - maps, censuses, court proceedings and general observations on the state of the communities.

Patrol Officers' contacts in the villages were the Village Constables and Councillors, appointed under the Native Regulations (Commonwealth of Australia 1952, 24). These men in turn kept records of village affairs to submit to the Patrol Officer. They also organised for villages, paths and rest houses used by the patrol, to be maintained in good order. It was these local men who appear to have done most of the work of governing the villages between the periodic visits of the Patrol Officer. 
The actual contacts between Patrol Officers and locals appear to have been overwhelmingly focussed on vision. Patrol reports, often completed at long intervals, forego much discussion of the context or background of states of affairs on the ground, but rather report them as a mise en scene. ${ }^{16}$ This is understandable, given the essentially visual techniques employed to police locals. Villagers were expected to form a 'census line' for a roll-call, which was then inspected by the Patrol Officer (see for example MacLeod 1946b; Johnston 1946). People had to 'appear' in person, and their appearance was noted by the Patrol Officer. Houses and gardens were looked at in a similar way. Praise and punishment was meted out as a result of these visual appraisals of the village (on this 'modern gaze' see Foucault 1994; Scott 1998).

This emphasis on the visual in the techniques of colonial governance is important because of the way it connects with ways in which Panapompom people today habitually talk about events and intentions (c.f. Hirsch 2004; 2007). Panapompom people, in common with many people throughout PNG, are most unwilling to speculate on things which have yet to transpire, either because they are in preparation, or exist merely as plans harboured by particular people (Leach 2003). Rather, they lay stress on what appears, masal, especially on the achievement of 'making something appear', pamasal (similar accounts of orchestrations of appearance are common in PNG, e.g. Clay, 1991; Merlan \& Rumsey, 1991; O'Hanlon, 1983; Strathern, 1991; Wagner, 1986). Anything prior to this appearance is hard to discuss, because the visible presence of something is tantamount to knowledge of it: ta kite, we (incl.) see and ta atena, we know, are often synonymous; similarly, panpan-kite (literally, cause to see) means 'teach', while papaatena (literally, cause to know) means 'preach'.

Colonial forms of governance must, then, have been highly accessible, on one level, to Panapompom people. ${ }^{17}$ Presenting oneself in a particular way and being known as - being, even - a particular kind of person is the same action. Therefore, colonial demands that local people present themselves in a particularly clean, disciplined and rectilinear form most likely appeared to Panapompom people as a new technology of personhood (Fife 2001; Filer 2006; Mosko 2002), which offered to remake them in a particular way. ${ }^{18}$ Specifically, this person was disciplined, clean, and peaceful and lived by legal rules dispensed by the white patrol officers via their local agents.

From the 1950s onwards, colonial officers were offering local people an improved material standard of living (in contradistinction to the church, which offered a superior spiritual standard) in return for compliance with these standards of behaviour - their reiteration. This was initially to be achieved through the growing of coconuts for copra production. Patrol officers encouraged local plantations and, later, the administration sponsored the establishment of locally owned co-operative societies, which produced copra and managed stores. Co-operative societies were mooted immediately after the War (Commonwealth of Australia 1948), and the first co-ops were established in the Sub-District in the period 195254, over the objections of expatriate plantation owners (MacLeod 1955).

This occurred within living memory; local oral histories of the copra co-operative and the other plantations that were flourishing at that time make it clear that ideas about appearance and development were intimately connected in this project. This is particularly 
clear in the way older men talked about the (now derelict) copra shed, on the north coast of Panapompom, which was built of galvanised iron plate, with a solar panel powering lights and a shortwave radio. Here development as a moral quality was manifest in the appearance of the place.

The framing image that defined 'development' in terms of colonial governance was the clean, peaceful and orderly village as seen by a white patrol officer. It was the performance for this person which surely motivated what Panapompom people understood by development as a visual technique for becoming people of a particular kind. As in the case of football strips or of cheering, an image becomes the mimetic entrée to a different way of being (Stoller 1989a; 1997; Taussig 1993).

\section{Native slippages}

However, this synergetic relationship between colonial forms of governance and local ways of knowing was, and continues to be, based on a slippage; we might say the play of lack and excess implicit in reiterating forms at different times and places. Colonial officers were less interested in the mimetic performance of particular types of personhood than they were in changing and controlling the traits and characters that those performances implied (Holston 1989; Stoller 1989b; 1997). Although native performance might look as the Patrol Officers wanted, it elicited a different take on its foundations; reports are filled with diatribes against Village Constables and others who were content merely to act the part of civilised people while continuing with their native lives unreformed (for example Middleton 1944). For the patrol officers, the orderly appearance of villages and natives were signs of inner, sincere states of change (although more often the lack of such change: Driver 1949), whereas for locals, it seems plausible to argue that these appearances were themselves effective in producing those changes. ${ }^{19}$ For Patrol Officers, there was always a truth to be exposed underneath the appearances that natives presented; for locals, there was always another way of living to be covered over (Robbins 1998; Rollason 2008b).

This slippage between appearance and its results exploded onto the footballing scene with the eruption of fighting, with what seemed, in hindsight, an awful inevitability. There were a number of large and violent fights, right from the beginning of the Association's league, culminating in the particularly embarrassing brawl in which the local Pastor was embroiled.

The very first fight was over a series of disagreements which erupted over team selection in one of the season's early games. Kenes, who had arrived too late to be selected to play for Kools, became angry. He went over to Seakings' supporters who were themselves disgruntled with the ease with which Kools were defeating their team. Kenes' abuse fuelled Seakings' anger on and off the pitch, until a moment of frustration between Seakings' goalkeeper, Sibauna, and one of his full-backs sparked an angry pitch invasion by the irate supporters. This in turn provoked a general running brawl, which flowed up and down the football field until tempers were finally quenched by a sudden downpour.

Sigi, a Trials player, former pastor and elementary teacher, had nothing but regretful condemnation for what had happened as he sat in tears on the floor of our house after the fight. 'Because of this, we shall never be developed,' he said, 'we shall never go and play for 
trophies in other places/countries (panuwa). We shall just stop here and that's all'. Other players and older men agreed. They saw the violence that erupted first as a revelation of the quality of Panapompom people, an excess escaping from the performance of goodwill, and secondly as something that confined them to a frustratingly limited context.

The quality of Panapompom people was often commented on with respect to my own role in the Association as a player and a white person. I was engaged, wholly against my will, and in a voice I did not use, as a critic and censor (Rollason 2008b): I must find the standard of football poor in Papua New Guinea - it was surely nowhere near as good as I was used to. In these moments, I found myself curiously doubled. Although I could not authoritatively offer Panapompom people relief from the domination of football by substituting polo shirts for football strips, opinions that I did not hold and would never have expressed - that Panapompom people are nothing but useless kanakas (Neo-Melanesian Pidgin for 'bumpkin') - became the only possible view I could take, and which, by default, I was assumed to subscribe to. ${ }^{20}$ In this way, I became the judge of Panapompom people through the entanglement of my material, historical, and deeply felt body in other people's politicalhistorical consciousness, resulting in the reduplication of voices and postures masquerading as my own (Marcus 1995).

What Panapompom people discovered in these judgements was an image of themselves as, as they put it, 'primitive', 'natives', kanakas and savages. These were interior states revealed in the appearance of Panapompom people's game not by their good behaviour, but by the recurrent eruption of violence and bad behaviour, which they had worked to suppress by covering it over with a show of civility.

When there was fighting Panapompom players discovered that football was a way of finding out the truth about themselves (Foucault 1990). Defining themselves through reiterating the powerful form of football, Panapompom people were opening up a space where they could reasonably judge themselves as comparable-but-not-as-good instantiations of footballers in the contextualising work of copying (Rollason 2008c). The appearance of the game created football as strangely dislocated from Panapompom, and relocated elsewhere, in or relative to the homes of white people dimdim panuwana. The watchful, disapproving gaze of white people (and myself) offered Panapompom people a very large field of potential relationships in which their qualities could be imagined and judged: their failings as footballers, as Sigi's remarks demonstrate, were to be imagined beyond the immediate inter-island community. But this extensive context of condemnation was simultaneously one which located Panapompom low in a hierarchy of footballing excellence and constrained local people from making moves on football in other places. Mokoli, president of the Association, had this comment:

Argentina wali standard i getoga hot [...] bahi matamiu ni nek [Argentina wali standard eliyana]... Ama wama standard eliyana

The standard [of football] in Argentina is completely different [...] don't even look at Argentina [...] we have to go by our own standard 
Fighting, here seen as a breach of the a required 'standard' served to establish a perspective in which Panapompom was at once comparable to, but not as good as, Argentina as a site of dimdim football. The upshot is a new self-knowledge and a new capacity to see the native self in terms of the project of football. This was the result of football as a mimetic, reiterative project - of the opening up of the context of football with which I began this paper.

\section{The subject of football}

In conclusion, I wish to return to the notion of football as a kind of political project with important effects for how Panapompom people understand themselves in relation to others, and to suggest another question which relates more broadly to theory and methodology in anthropology, especially in the Pacific: how do we handle problems of context when ethnographic subjects make moves on similarity, and how does this affect what we can know about these people?

To recapitulate, what kind of project was football for Panapompom people? It is clear in the first place that Panapompom people are not interested in maintaining the integrity of the cultural context in which they exist. Indeed the project of development is to be seen as a systematic transgression of a limited, integrated context in which action is to be made sense of, in favour of a much broader and more dangerous field of possibilities - this work of prospecting (Battaglia 1995; Rollason 2009; 2010a) for other powers and possibilities is central to what Panapompom people see themselves as doing. The means by which they do this is through the replication of football as development - a mode of practice that has its roots in the colonial past and its synergies with indigenous ways of knowing. This offers an explanatory framework for the disturbing obviousness or transparency of football with which I began the paper. It also demonstrates that it matters profoundly that Panapompom people are doing football and not, for example 'custom' or 'culture'. The sorts of contexts opened up even by pan-Melanesian or pan-Pacific enactments of custom are not populated by the same kinds of people, and they are related in different ways (c.f. Hau'ofa 1999; Kasaipwalova 1974; Keesing 1992). Football serves Panapompom people's project because of the sorts of linkages that it establishes to the 'homes of white people'.

This transgressive move is articulated through a systematic mimetic attempt to reiterate football. In a sense, this way of engaging football in itself suggests a specific cultural context, defined by what Lattas has called 'modes of creativity' (Lattas 1998; Lattas 2006b). In Lattas' terms, football appears as a 'mirroring' term in which Panapompom people see themselves in relation to white people. However, whereas the Kaliai villagers from New Britain Lattas studied appear, in his account, to be engaged in a project $s$ by which their modes of mimetic other-appropriation co-opt, corrupt and reuse modes of colonial power as part of a more or less conscious political project, Panapompom people see themselves as doing something different: Panapompom people's project of football is not about the defence of a native position against encroaching colonial power, rather it is about displacing the self, through development' to make it less native and more like a white person. In Judith Butler's apposite terms 'reiteration' appears to be the project here (Butler 1990; 1995; 1997). Doing football is 
a powerful act that elicits the context not of Panapompom culture, but of football as a global sport.

Reiteration, rather than replication, is apt here, for Panapompom football clearly does not conform to the universalising project of the IOC, or of international sporting bodies more generally. In the first place, Panapompom engagements with football aim to replicate the game, but they do not thereby render it unproblematic. The IOC rhetoric that I cited (International Olympic Committee 2007) tends to assume the straightforward portability of games and sports, such that the form of the game is itself a guarantee, first of how it is to be played, and second of the sorts of moral effects that it is to have. In short, these ideas propose a situation in which both the 'meaning' of the game as a sign and the quality of the subjects that it produces can be read off the sport itself in advance.

Panapompom uses of football, however, confound this sort of perspective. In the first place, understanding why Panapompom people play football in a specific historical context, defined in part by their long-term engagement with colonial powers. The project of development that they entertain has certain resemblances with the IOC's project - enough, no doubt, to bracket them together for some purposes - but development in its guise of becoming white through technologies of imitation and possession is surely not an aspiration that the IOC would subscribe to. The ways in which football is reproduced and framed, and the reasons for playing the game are specific. Football may be football, but it is in the service of a distinctive project.

Butler's notion of reiteration embeds two ideas, which are very useful here (Stern 2000). First, following a well-worn line in post-structural theory, she notes that people do not invent the signs and discourses that they make use of (Butler 2005). Panapompom people have clearly not invented football. Indeed, they deliberately resist any sort of invention in the way they enact the game: short-cuts like polo shirts are not acceptable. Rather it is an adoption that makes sense of the world in a particular way, defined by others - here Butler's argument is very close to Wagner's (1975) discussion of context that I introduced earlier.

Secondly, however, the use of signs and discourses is itself context-bound. Signs, words, discourses have no social effect unless they are used - re-enacted as the actions of specific bodies, or spoken to particular ends. Here Butler's argument is that the use of contextualising terms is itself the act of defining context (Butler 1995). So Panapompom people both adopt the notion of football as a framing image for what they are doing, and redefine the boundary of football in terms of the aims that they are working towards - all this in the context of a project that seeks to reform who they are.

Moreover, Butler's theory of reiteration implies that subjects themselves are on the move just as much as their contexts. Making a claim on contextualising motif is never to establish an identity: symbols never exhaust the subject, 'there is no doer behind the deed' (Butler 1990). Rather, she charts the tense positioning of a speaker relative to the spoken in the struggle to be intelligible and occupy certain valued positions (c.f. Battaglia 1999): this is an exercise in strategic approximation rather than absolute sameness, and challenges us with the vertiginous space between proffered identities - exactly that site of prospecting that 
Panapompom footballers open up between their 'native' cultural context and the universalising project of football.

This is not simply a plea for greater sensitivity in ethnographic work. Rather it leads to a broader question about how ethnographers confront other people whose degree and mode of otherness is not obvious. Whilst especially in Melanesia it has been tempting for anthropologists to imagine that that otherness is absolute, the risks of taking that view are enormous: Melanesians have found themselves pinned down under the weight of their own distinctiveness. ${ }^{21}$ Reiterating football, displacing both their native culture and unproblematic readings from global cosmopolitan positions, Panapompom people need to be seen as people on the move as they negotiate the demands and possibilities of the post-colonial scene, rejecting relativised roots as much as universalist presumptions.

\section{Acknowledgements}

This paper is based on eighteen months of fieldwork carried out in collaboration with Panapompom footballers between 2004 and 2006 and funded by an ESRC studentship. I wish to thank Karen Sykes, Joel Robbins, Ryan Schram, Keir Martin and Alice Street who offered advice, comment, enthusiasm and support at various stages of its gestation.

${ }^{1}$ This argument is motivated by Butler's theory of reiteration, in which the reproduction of certain forms of discourse serve metaphorically to define subjects, acts and relationships that are performed by the act of reiteration (Butler, 1990). Butler's argument is useful because, although she draws inspiration from theories of speaking and discourse, it is the performance of sexual acts that stands at the heart of her analysis: she recognises the way in which a singleminded attention to speech and writing fatally decomposes the subject (Butler 1989).

${ }^{2}$ These people were both men and women. The women were to go on to play netball, the men football. This paper deals with football as it is on football that my data is strongest, and this was the game I was involved in personally.

${ }^{3}$ The Kina is the currency of PNG. During my fieldwork, K1 was worth approximately $£ 0.17$.

${ }_{5}^{4}$ Jeff Kinch generously supplied household survey data which assisted in making this estimate.

${ }^{5}$ In this essay I treat Panapompom football as a reiteration rather than a ritual performance - an analysis that would also be possible. I have used this framework deliberately in order simultaneously to distance the analysis from typically 'othering' accounts of Melanesians (typically based in analyses of ritual symbols), and to suggest the similarities between my analysis of social life on Panapompom and approaches by post-structuralist and feminist scholars, a synergy that I think it strategically useful to pursue given the often-stressed alterity of Melanesians in general. The 'magic' deployed by Panapompom people is therefore not the magic of ritual, but the magic of the photographic image in this account, a concern shared by scholars of the Frankfurt school (Taussig, 1993).

${ }^{6}$ Anthropologists model context either in terms of a structure, or in terms of a hermeneutic (Dreyfus, Rabinow, and Foucault 1983). For the purposes of this discussion the distinction is moot.

${ }^{7}$ The other principal trope is, of course, society. However, with the relativisation of the notion of 'the relation' that has taken place in Melanesian anthropology over the last two decades, it is less and less clear what the distinction between culture and society is (e.g. Strathern 1988; 1992; 1991 etc.; Wagner 1967; 1991). As I am mainly engaging with American cultural anthropologists in this paper, I have found it convenient to accept Wagner's assertion of the primacy of the concept of culture.

${ }^{8}$ This is obvious in structuralist accounts such as Sahlins' (especially 1981; 1995; 2000). However, it is equally true of hermeneutic accounts (e.g. Geertz 1980). Here everything is understood not in terms of structure, but of a regression of meanings which reach back and down into 'deeper' regions of significance.

${ }^{9}$ This is not the same as the stereotyped claim that cultures are necessarily holistic and potentially static constructs. This is not the critique that I am advancing here.

${ }^{10}$ Interestingly, this is exactly the way in which Strathern (1988) portrays the workings of 'Melanesian agency', in which the act of transacting defines the relationship in which the transaction takes place and 
elicits the next. The difference is that in the context of football the frame of possible transactions is not fixed as in Strathern's model.

${ }^{11}$ This is essentially Robbins' position with respect to Pentecostal Christianity. Robbins and I differ on our treatment of culture in that in Becoming Sinners (Robbins 2004), Robbins' analysis depends on the notion that people can entertain more than one culture. This makes the subject who shuttles between cultures paradoxically a-cultural. My response is to attempt to maintain t a certain strategic ambiguity (Battaglia 1999) by refusing to identify people with the cultural contexts that might make them provisionally intelligible (see Rollason 2010b).

${ }^{12}$ Both these scholars echo Appadurai's contention that cricket is highly portable between cultural contexts because it resists its piecemeal alteration or reinterpretation and thus holds an authority over people that makes its original terms effective even across cultural contexts (Appadurai 1996, 90).

Robbins, indeed, builds on this argument in appealing for anthropologists to take Christianity seriously on its own terms, rather than insisting on its continuous modification by culture (Robbins 2004; 2007).

13 'Lads' quite accurately glosses the Panapanaeati gemenau as it is used between football players. It is an expression of equality and friendship between men of low status, stressing youth and energy. I cannot do justice here to the rich literature on masculinity in the (see for example Taylor 2008; Taylor 2010; Margaret Jolly 2008; Lipset 1997). As Panapompom people did not talk about football in these terms, I do not feel that I am neglecting a central aspect of this ethnographic case by focussing on race, rather than gender.

${ }^{14}$ The name Panapompom literally translates as 'land [of]' (pana-) 'filiarisis' (pom). Filiarisis is a mosquito-borne parasite that causes massively enlarged limbs and genitals in a condition known as elephantiasis. Panapompom people regard this as evidence and an effect of witchcraft and incest.

${ }^{15}$ The Annual Reports for the Territory, Submitted to Canberra, describe this process.

${ }^{16} \mathrm{My}$ analysis here is influenced by philosophical analyses of photographs' ambiguous relationship to time - as either always in the past (Sontag 1977) or as objects independent of their histories (Flusser 2000).

${ }^{17}$ Lattas (1998; 2006a) makes a very similar point - drawing on Scott's (1998) account of the role of performance and the aesthetics of the modern state to argue, with Foucault $(1991 ; 1994 ; 1995)$, that modern governance is essentially visual and mimetic. Butler's notion of reiteration shifts the terms of the argument slightly - away from the 'legible' world and towards the body (Butler 1989).

${ }^{18}$ Compare this suggestion with the widespread practices of imitation associated with cargo cult activity - marching, keeping 'records', building wireless stations and so on (Burridge 1995; Lattas 2006a; Lawrence 1967; Lindstrom 1990; 1993; Worsley 1968).

${ }^{19}$ Once again, material on cargo cults is worth citing here, especially Lattas' excellent treatment of mimesis and the 'domestication' of white power by Kaliai people (Lattas 1998; see also Lipset 2004). Note however, that Panapompom people are concerned with their own self-domestication as a means of access to the other's power, rather than capturing the other through mimesis in order to control them (a suggestion from Benjamin 1986; adopted and developed by Taussig 1980; 1986; 1993).

${ }^{20} \mathrm{I}$ am indebted to Amy Pollard for this observation.

${ }^{21}$ It is perhaps surprising that this argument continues to be necessary. However, there seems to be an abiding commitment - unfortunately in my view - to Melanesians' absolute distinctiveness (e.g. Mosko 2010).

\section{References}

\section{Published sources}

Appadurai, Arjun. 1996. Modernity at large: cultural dimensions of globalization . Minneapolis, Minn.: University of Minnesota Press.

Anderson, Benedict. 1991. Imagined communities: reflections on the origin and spread of nationalism. London; New York: Verso.

Bashkow, Ira. 2006. The meaning of whitemen: race and modernity in the Orokaiva cultural world. Chicago: University of Chicago Press.

Battaglia, Debbora. 1990. On the bones of the serpent: person, memory, and mortality in Sabarl Island society. Chicago: University of Chicago Press. 
1995. On practical nostalgia: self-prospecting among urban Trobrianders. In Rhetorics of self-making, 77-96. Berkeley, CA. \& London: University of California Press.

1999. Towards an ethics of the open subject. In Anthropological Theory Today, 114-150. Cambridge: Polity Press.

Benjamin, Walter. 1986. Illuminations. New York: Schocken Books.

Berde, Stuart. 1974. Melanesians as Methodists: economy and marriage on a Papua and New Guinea Island. Pennsylvania: University of Pennsylvania, Anthropology.

1979. Impact of Christianity on a Melanesian economy. Research in Economic Anthropology 2: 169-187.

Bromilow, William Edward. 1929. Twenty years among primitive Papuans. pp. 316. Epworth Press: London.

Burridge, Kenelm. 1995. Mambu: a Melanesian millennium. Princeton, N.J.: Princeton University Press.

Butler, Judith. 1989. Foucault and the paradox of bodily inscriptions. The Journal of Philosophy 86, no. 11: 601-607.

- 1990. Gender trouble: feminism and the subversion of identity. Thinking gender. New York: Routledge.

1993. Bodies that matter: on the discursive limits of "sex". New York: Routledge.

1995. Contingent foundations. In Feminist contentions: a philosophical exchange, 35-58. New York: Routledge. . 1997. The psychic life of power: theories in subjection. Stanford, CA.: Stanford University Press.

1999. Revisiting bodies and pleasures. Theory, Culture and Society 16, no. 2: 11-20. 2005. Giving an account of oneself. 1st ed. New York :

Commonwealth of Australia. 1948. Territory of Papua, annual report 1947/48.

- 1952. Territory of Papua and New Guinea Annual Report 1951/52.

Connell, John. 1997. Papua New Guinea: the struggle for development. London; New York: Routledge.

Dreyfus, Hubert L., Paul Rabinow, and Michel Foucault. 1983. Michel Foucault: beyond structuralism and hermeneutics. Chicago: University of Chicago Press.

Englund, Harri, and James Leach. 2000. Ethnography and the meta-narratives of modernity. Current Anthropology 41, no. 2: 225-248.

Fife, Wayne. 2001. Creating the moral body: missionaries and the technology of power in early Papua New Guinea. Ethnology 40, no. 3: 251-269.

Filer, Colin. 2006. Custom, law and ideology in Papua New Guinea. The Asia Pacific Journal of Anthropology 7, no. 1: 65-84.

Flusser, Vilém. 2000. Towards a philosophy of photography. London: Reaktion Books.

Foster, Robert John. 1999. The comercial construction of 'new nations'. Journal of Material Culture 4, no. 3: 263-282.

2002. Materializing the nation: commodities, consumption, and media in Papua New Guinea. Bloomington \& Indianapolis, Ind.: Indiana University Press. 2006. From Trobriand Cricket to rugby nation: the mission of sport in Papua 
New Guinea. The International Journal of the History of Sport 23, no. 5: 739758.

2008. Commodities, brands, love and kula: comparative notes on value creation in honour of Nancy Munn. Anthropological Theory 8, no. 1: 9-25.

Foucault, Michel. 1990. The history of sexuality. London: Penguin Books.

- 1991. Governmentality. In The Foucault effect: studies in governmentality, 87-104. London: Harvester Wheatsheaf.

. 1994. The birth of the clinic: an archaeology of medical perception. New York: Vintage Books.

1995. Discipline and punish: the birth of the prison. New York: Vintage Books.

Geertz, Clifford. 1973. Thick description: toward an interpretive theory of culture. In The interpretation of cultures: selected essays by Clifford Geertz, 3-30. New York: Basic Books.

1980. Negara: the theatre state in nineteenth-century Bali. Princeton, N.J.: Princeton University Press.

Hau'ofa, Epeli. 1999. Our sea of islands. In Inside out: literature, cultural politics, and identity in the new Pacific, 27-38. Lanham, Md.: Rowman \& Littlefield.

Hirsch, Eric. 2004. Techniques of vision: Photography, disco and rendrings of present perceptions in Highland Papua. Journal of the Royal Anthropological Institute 10, no. 1: 19-39.

2007. Looking like a culture. Anthropological Forum 17, no. 3: 225-238.

Holston, James. 1989. The Modernist City: An Anthropological Critique of Brasilia. Chicago: University of Chicago Press.

International Olympic Committee. 2007. Olympic Charter (in force as from 7th July 2007). International Olympic Committee.

Kasaipwalova, John. 1974. 'Modernising' Melanesian society - why, and for whom? In Priorities in Melanesian Development. Canberra: Australian National University.

Keesing, Roger M. 1992. Custom and confrontation: the Kwaio struggle for cultural autonomy. Chicago: University of Chicago Press.

Kinch, Jeff. 2002. Overview of the bêch-de-mer fishery in Milne Bay Province, Papua New Guinea. SPC Bêch-de-mer Bulletin 17: 2-16.

Kulick, Don, and M.E. Wilson. 1992. Echoing images: the construction of savagery among Papua New Guinean villagers. Visual Anthropology 5: 143-52.

Lattas, Andrew. 1998. Cultures of secrecy: reinventing race in bush Kaliai cargo cults. New directions in anthropological writing. Madison: University of Wisconsin Press.

- 2006. The utopian promise of government. Journal of the Royal Anthropological Institute 12: 129-150.

2006. Technologies of visibility: the Utopian politics of cameras, televisions, videos and dreams in New Britain. The Australian Journal of Anthropology 17, no. 1 : $15-31$.

Lawrence, Peter. 1967. Road Belong Cargo: a Study of the Cargo Movement in the Southern Madang District, New Guinea. Carlton, Melbourne; Manchester: Melbourne University Press; Manchester University Press.

Leach, James. 2003. Creative land: place and procreation on the Rai Coast of Papua New Guinea. New York: Berghahn Books. . 2006. 'Team spirit': the pervasive influence of place-generation in 
'community building' activities along the Rai Coast of Papua New Guinea. Journal of Material Culture 11, no. 1: 87-103.

Lindstrom, Lamont. 1990. Knowledge and power in a South Pacific society.

Smithsonian series in ethnographic inquiry. Washington: Smithsonian Institution Press.

1993. Cargo Cult: Strange Stories of Desire from Melanesia and Beyond. South Sea books. Honolulu: Center for Pacific Islands Studies, School of Hawaiin, Asian, and Pacific Studies University of Hawaii Press.

Lipset, David. 1997. Mangrove man: dialogics of culture in the Sepik estuary. Cambridge University Press, November 13.

. 2004. 'The trial': a parody of the law amid the mockery of men in postcolonial Papua New Guinea. Journal of the Royal Anthropological Institute 10, no. 1 (3): 63-89.

LiPuma, Edward. 1995. The Formation of Nation States and National Cultures in Oceania. In Nation Making: Emergent Identities in Postcolonial Melanesia. Ann Arbor: University of Michigan Press. . 2000. Encompassing others: the magic of modernity in Melanesia. Ann Arbor: University of Michigan Press.

MacAloon, John J. 2006. Introduction: Muscular Christianity after 150 years. The International Journal of the History of Sport 23, no. 5: 687-70.

Maguire, Joseph A. 2005. Power and global sport: zones of prestige, emulation and resistance. London; New York: Routledge.

Mangan, J.A. 2006. Christ and the imperial playing fields: Thomas Hughes's ideological heirs in empire. The International Journal of the History of Sport 23, no. 5: 77-807.

1995. On eccentricity. In Rhetorics of self-making, 43-58. Berkeley CA: University of California Press.

Margaret Jolly. 2008. Moving Masculinities: Memories and Bodies Across Oceania. The Contemporary Pacific 20, no. 1: 1-24.

Moore, Henrietta L. 2004. Global anxieties: concept metaphors and pre-theoretical commitments in anthropology. Anthropological Theory 4, no. 1: 71-88.

Mosko, Mark. 2010. Partible penitents: dividual personhood and Christian practice in Melanesia and the West. Journal of the Royal Anthropological Institute 16, no. 2 (6): 215-240.

Mosko, Mark S. 2002. Totem and transaction: the objectification of tradition among the North Mekeo. Oceania 73, no. 2: 89-110. 2007. Fashion as Fetish: the agency of modern clothing and traditional body decoration among North Mekeo of Papua New Guinea. The Contemporary Pacific 19, no. 1: 39-83.

Nelson, Hank. 1976. Black, white and gold: gold mining in Papua New Guinea, 18781930. Canberra: Australian National University Press. 1982. Taim bilong masta: the Australian involvement with Papua New Guinea. Sydney: Australian Broadcasting Commission. 2000. Liberation: the end of Australian rule in Papua New Guinea. The Journal of Pacific History 35, no. 3: 269-280.

Norwegian Olympic Development Committee. n.d. Sport and development cooperation: sport influencing lives. Norwegian Olympic Development Committee.

Read, Kenneth E. 1959. Leadership and consensus in a New Guinea society. 
American anthropologist 61: 425-436.

Robbins, Joel. 1998. Becoming sinners: Christianity and desire among the Urapmin of Papua New Guinea. Ethnology 37, no. 4: 299-317.

. 2004. Becoming Sinners: Christianity and Moral Torment in a Papua New

Guinea Society. Ethnographic studies in subjectivity. Berkeley, Calif.:

University of California Press.

. 2007. Continuity thinking and the problem of Christian culture. Current Anthropology 48, no. 1: 5-38.

Rollason, Will. 2008. Counterparts: clothing, value and the sites of otherness in Panapompom ethnographic encounters. Anthropological Forum 18, no. 1: 1735 .

2008. Black skin, white yacht: negotiating race opposition in Panapompom tourist encounters. Tourism, culture and communication 8, no. 2: 109-122. 2008. Football and postcolonial subjectivity, Panapompom, Papua New Guinea. Manchester: University of Manchester, Social Anthropology. 2009. Diving One Man: disconnection and recontexualization among Panapompom bêche-de-mer divers. Cambridge Anthropology 28, no. 2: 45-62. 2010. My Boss: Insincerity, Capitalism and Development in PNG. Etnofoor. . 2010. Working out abjection in the Panapompom bêche-de-mer fishery: race, economic change and the future in Papua New Guinea. The Australian Journal of Anthropology 21(2): 149-170.

Sahlins, Marshall David. 1981. Historical metaphors and mythical realities: structure in the early history of the Sandwich Islands Kingdom. ASAO special publications. Ann Arbor: University of Michigan Press.

_ 1995. How "natives" think: about Captain Cook, for example. Chicago: University of Chicago Press. 2000. The return of the event, again. In Cultre in Practice: selected essays, 293-351. New York: Zone Books. . 2005. The economics of develop-man in the Pacific. In The making of global and local modernities in Melanesia: humiliation, transformation and the nature of cultural change, 23-42. Aldershot, Burlington VT: Ashgate.

Scott, James C. 1998. Seeing like a state: how certain schemes to improve the human condition have failed. Yale agrarian studies. New Haven: Yale University Press.

Skewes, T., J. Kinch, P. Polon, D. Dennis, P. Seeto, T. Taranto, P. Lokani, T. Wassenberg, A. Koutsoukos, and J. Sarke. 2002. Research for sustainable use of beche-de-mer resources in Milne Bay Province, Papua New Guinea.

Sontag, Susan. 1977. On photography. New York: Farrar, Straus and Giroux.

Stern, D. 2000. The return of the subject? Power, reflexivity and agency. Philosophy and Social Criticism 26, no. 5: 109-122.

Stoller, Paul. 1989. Fusion of the Worlds: an Ethnography of Possession Among the Songhay of Niger. Chicago: University of Chicago Press. . 1989. The taste of ethnographic things: the senses in anthropology. Contemporary ethnography series. Philadelphia: University of Pennsylvania Press. 1997. Sensuous scholarship. Contemporary ethnography. Philadelphia: University of Pennsylvania Press.

Strathern, Marilyn. 1979. The self in self-decoration. Oceania 49, no. 4: 241-257. . 1988. The gender of the gift: problems with women and problems with 
society in Melanesia. Studies in Melanesian anthropology ; 6. Berkeley: University of California Press.

. 1991. Partial connections. ASAO special publications. Savage, Md.:

Rowman \& Littlefield Publishers.

1992. Qualified value: the perspective of gift exchange. In Barter, exchange and value, and anthropological approach, 169-192. Cambridge \& New York: Cambridge University Press.

1995. The relation: issues in complexity and scale. Cambridge: Prickly Pear Press.

Sykes, Karen. 1999. After the raskol feast: youths' alienation in New Ireland, Papua New Guinea. Critique of Anthropology 19, no. 2: 157-174.

Taussig, Michael T. 1980. The Devil and Commodity Fetishism in South America. Chapel Hill: University of North Carolina Press.

1986. Shamanism, colonialism, and the wild man: a study in terror and healing. Chicago: University of Chicago Press.

1993. Mimesis and alterity: a particular history of the senses. New York: Routledge.

Taylor, John P. 2008. Changing Pacific Masculinities: The 'Problem' of Men. The Australian Journal of Anthropology 19, no. 2: 125-135.

. 2010. Janus and the siren's call: kava and the articulation of gender and modernity in Vanuatu. Journal of the Royal Anthropological Institute 16, no. 2: 279-296.

UNDP. 2008. Partnership Agreement will Boost Use of Sports for Development, FIFA Boss Says.

www.undp.org.pg/sports_for_dev.html+football+development+papua+new+g uinea $\& \mathrm{hl}=\mathrm{en} \& \mathrm{ct}=\mathrm{clnk} \& \mathrm{~cd}=9 \& \mathrm{gl}=\mathrm{uk}$.

Wagner, Roy. 1967. The curse of Souw: principles of Daribi clan definition and alliance in New Guinea. Chicago,: University of Chicago Press. 1974. Are there social groups in the New Guinea Highlands? In Frontiers of anthropology. New York: Van Nostrand.

1975. The Invention of Culture. Englewood Cliffs, N.J.: Prentice-Hall. . 1991. The fractal person. In Big men and great men: personifications of power in Melanesia, 197-214. Cambridge: Cambridge University Press.

-2001. An anthropology of the subject: holographic worldview in New Guinea and its meaning and significance for the world of anthropology. Berkeley: University of California Press.

Wetherell, David. 1996. Charles Abel and the Kwato Mission of Papua New Guinea, 1891-1975. Carlton South, Vic., Australia: Melbourne University Press.

Wilde, Charles. 2004. From racing to rugby: all work and no play for Gogodala men of Western Province, Papua New Guinea. The Australian Journal of Anthropology 15, no. 3: 286-302.

Wolff, Bente. 2005. Disco, dog's teeth and women in uniforms: modern Mekeo dresscodes. In The art of clothing: a Pacific experience, 89-102. London: UCl Press.

Worsley, Peter. 1968. The Trumpet Shall Sound: a Study of "Cargo" Cults in Melanesia. 2nd ed. London,: MacGibbon \& Kee. 


\section{Colonial patrol reports}

Davies, F.I. (CPO). 1954. Misima No. 1 1954/55. 02-20/08/1954 \& 19, 21/07/1954.

Driver, F.G. (PO). 1949. Misima No. 7 1949/50. 02/12/49-22/12/49.

Geelan, R.M. (a/ADO). 1952. Misima No. 7 1951/52. 12/02/52-16/02/52.

Gerrard, P.A. (PO). 1969. Misima No. 4 1969/70. 16-20/10/69, 30-31/10/69, 3 4/11/69, 20/11/69-10/12/69.

James, C.R. (Lt). 1944. Misima No. 6 1943/44. 12/01/44-07/02/44.

Johnston, W.J. (PO). 1946. Misima No. 2 1946/47. 16/05/46-(end date not given).

MacLeod, John S. (a/ADO). 1946a. Misima No. 1 1945/46. 06/03/46-18/03/46. 1946b. Misima No. 1 1946/47. 16/05/46-27/05/46.

1955. Misima No. 2 1954/55. 25/01/1955-19/02/1955.

Mader, R.G. (Lt). 1942. Misima No. 2 1942/43. 21/11/42-02/12/42.

Middleton, F.I. (WOII). 1944. Misima No. 2 1944/45. 26/08/44-16/09/44.

Smith, Sydney (Lt). 1943. Misima No. 3 1942/43. 18/02/43-28/03/43.

Standing, J.A. (APO). 1971. Misima No. 1 1971/72. 20/09/71-01/10/71.

Teague, B.N. (PO). 1956. Misima No 2 1955/56. 06/03/56-20/03/56. 
$<<$ FIGURE ONE $>>$

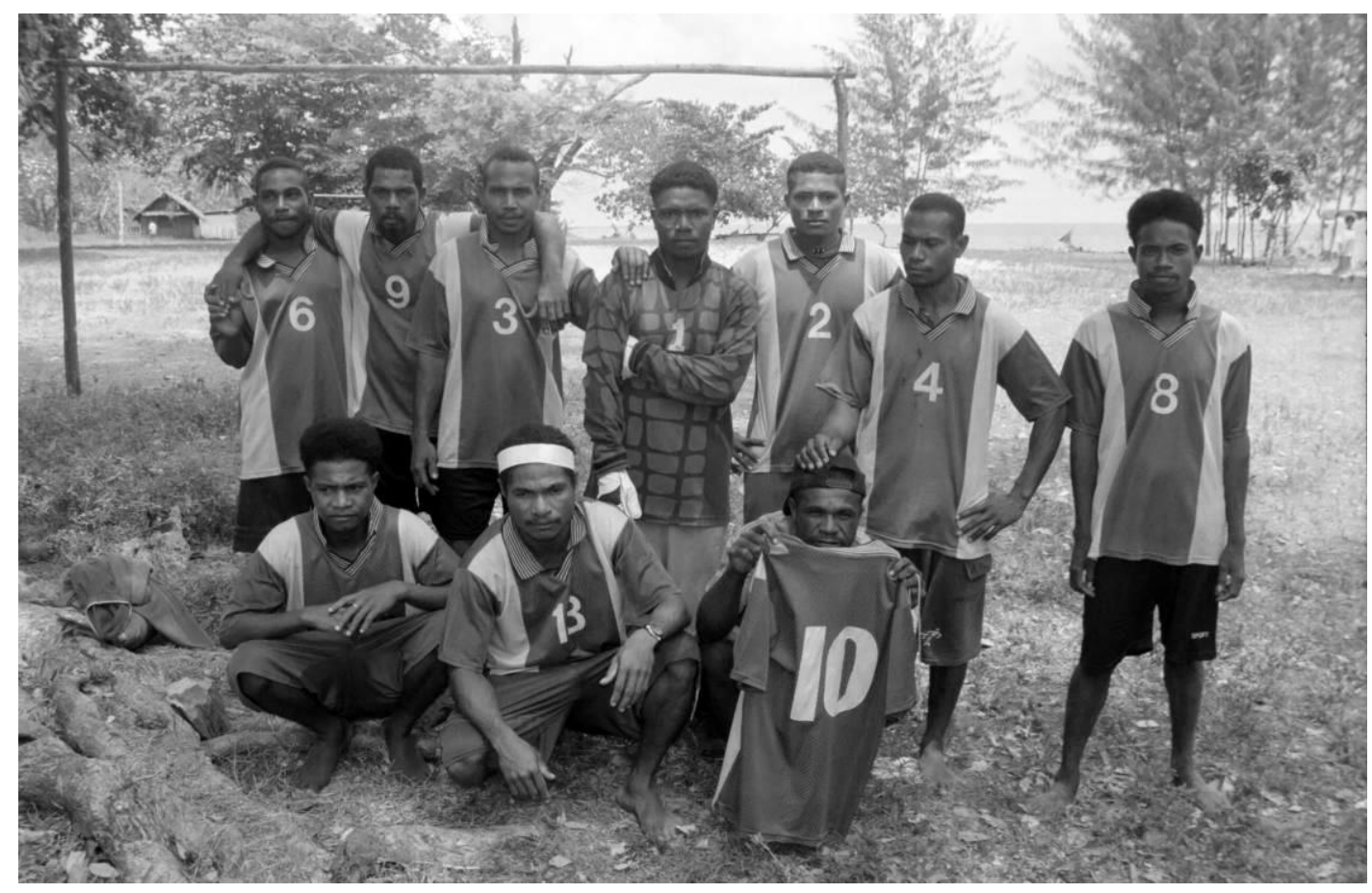


$<<$ FIGURE TWO >>

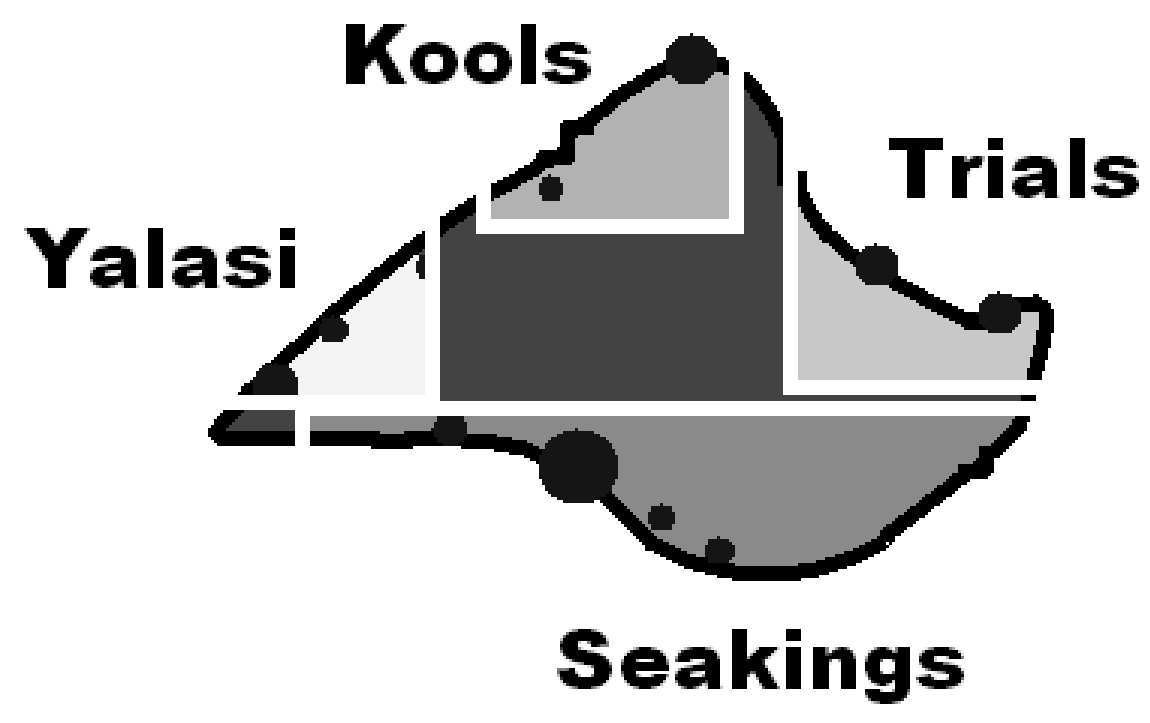

Location of Panapompom teams 


\begin{tabular}{|c|c|c|}
\hline Trials & $\begin{array}{l}\text { North-east villages, } \\
\text { associated with East } \\
\text { Panaeati. }\end{array}$ & $\begin{array}{l}\text { Inter Milan rip-off jersey in black and blue stripes with no } \\
\text { numbers purchased by Andy, one of the team captains and } \\
\text { trade-store owner. Plan to raise money to pay for the strips } \\
\text { failed to provide the needed amount. After the season, } \\
\text { ownership of the strip disputed and complicated by Andy's } \\
\text { defection to Yalasi. }\end{array}$ \\
\hline Kools & $\begin{array}{l}\text { Galowawaisana and } \\
\text { central north coast, } \\
\text { the school team. } \\
\text { Associated with } \\
\text { Ebola. }\end{array}$ & $\begin{array}{l}\text { Blue and yellow strip with numbers borrowed from Ebola on } \\
\text { the large island of Misima, a contact through the elementary } \\
\text { teachers who are from Ebola. The use of the strip made } \\
\text { complicated by the issue of whether the Ebola lads could } \\
\text { play for the association on Panapompom and the possibility } \\
\text { that they would be needed for the new Ebola association. }\end{array}$ \\
\hline Yalasi & $\begin{array}{l}\text { North-west villages, } \\
\text { associated with } \\
\text { south coast and } \\
\text { West Panaeati. }\end{array}$ & $\begin{array}{l}\text { Same Inter rip-off as bought by Trials. When the teams } \\
\text { played one another, one side turned their jerseys inside out } \\
\text { to distinguish themselves. This jersey purchased with club } \\
\text { money rather than paying it as fees to the association. After } \\
\text { the season, players took 'their' jerseys home with them as } \\
\text { their own clothing. }\end{array}$ \\
\hline Seakings & $\begin{array}{l}\text { South coast, } \\
\text { associated with } \\
\text { north-west villages } \\
\text { and West Panaeati. }\end{array}$ & $\begin{array}{l}\text { Lemon yellow strip with numbers and the team's name } \\
\text { printed on it. Used in the defunct football association at } \\
\text { Panaeati and retained by the leaders of the team. Originally } \\
\text { given to the team by one of the candidates in the } 2002 \\
\text { general election as an incentive to vote. }\end{array}$ \\
\hline
\end{tabular}

